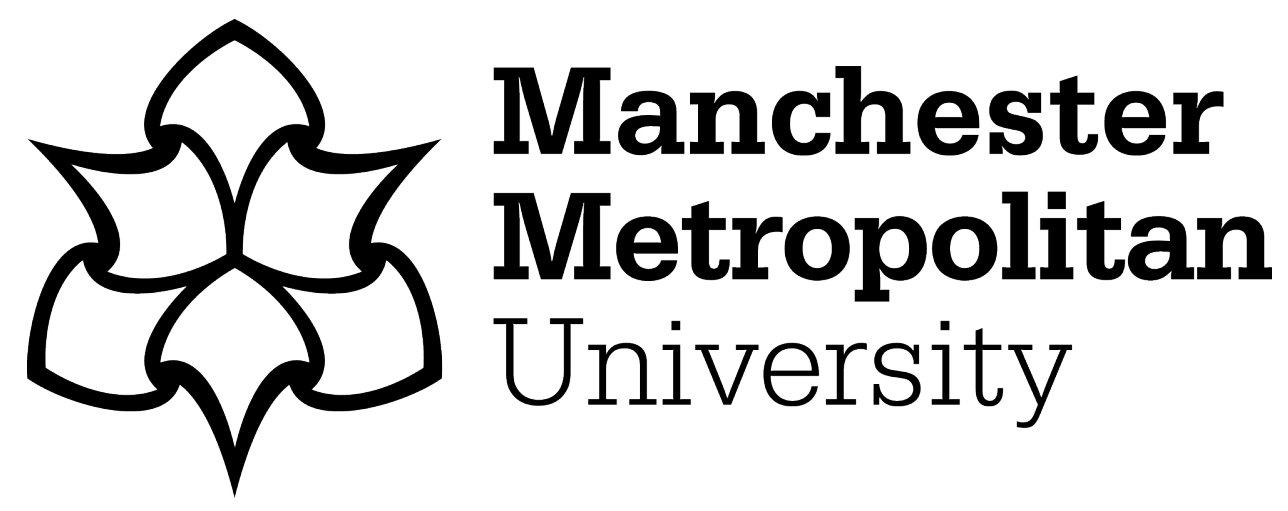

Kowalewska, G, Rutkowska-Ziarko, A, Simister, J and Sonmez, Y (2016) Where and Why in the UK? The Case of Polish Migrants. Olsztyn Economic Journal, 11 (2). pp. 137-150. ISSN 1897-2721

Downloaded from: https://e-space.mmu.ac.uk/621885/

Version: Published Version

Publisher: University of Warmia and Mazury in Olsztyn Publishing House

Please cite the published version 
OLSZTYN ECONOMIC JOURNAL

Abbrev.: Olszt. Econ. J., 2016, 11(2)

\title{
WHERE AND WHY IN THE UK? THE CASE OF POLISH MIGRANTS
}

\author{
Grażyna Kowalewska', Anna Rutkowska-Ziarko', \\ John Simister ${ }^{2}$, Yontem Sonmez ${ }^{2}$ \\ ${ }^{1}$ Department of Quantitative Methods \\ Faculty of Economics \\ University of Warmia and Mazury in Olsztyn \\ e-mail: kowalewskagrazyna@wp.pl, e-mail: aniarziarko@gmail.com \\ ${ }^{2}$ Accounting, Finance \& Economics Dept \\ Business \& Law Faculty \\ Manchester Metropolitan University Business School \\ e-mail: j.g.simister@mmu.ac.uk, e-mail: y.sonmez@mmu.ac.uk
}

Ke y w or d s: international migration, migrant workers, salary, unemployment rate, Polish people in UK.

\section{Abstract}

This article focuses on one of the most controversial issues frequently discussed by many including politicians, academics and the media in the UK and Poland: migration of Polish people to Britain. The main aim is to identify the important factors causing migration of Poles within the UK. In this article, the authors seek to study the pull factors, i.e. level of wages or employment rate, for Polish people between different regions within the UK. By using the data from "Labour Force Surveys" collected by the UK government; and data from Główny Urząd Statystyczny (GUS) in Poland, this paper analyses where and why the Polish migrants live in the UK.

The most important factor determining the fraction of Polish people in a given region is the fraction of Polish people in that region in the past. When Polish people move within UK, they tend to choose a region with a higher level of gross pay, and they don't seem to consider the risk of unemployment.

The authors are grateful to providers of survey data discussed in the "Data and methods" section of this paper. LFS data are made available by the UK Data Service. Views reported in this paper do not necessarily reflect opinions of organisations which commissioned or provided access to these surveys. 


\title{
GDZIE I DLACZEGO W WIELKIEJ BRYTANII? PRZYPADEK POLSKICH EMIGRANTÓW
}

\author{
Grażyna Kowalewska1, Anna Rutkowska-Ziarko', John Simister ${ }^{2}$, Yontem Sonmez $^{2}$ \\ ${ }^{1}$ Katedra Metod Ilościowych \\ Wydział Nauk Ekonomicznych \\ Uniwersytet Warmińsko-Mazurski w Olsztynie \\ ${ }^{2}$ Zakład Rachunkowości, Finansów i Ekonomii \\ Wydział Biznesu i Prawa \\ Uniwersytet Metropolitalny w Manchesterze, Szkoła Biznesu
}

\begin{abstract}
Słowa kluczowe: międzynarodowe migracje, pracownik-emigrant, wynagrodzenie, stopa bezrobocia, Polacy w Wielkiej Brytanii.
\end{abstract}

\section{Abstrakt}

W artykule skupiono się na jednym z najbardziej kontrowersyjnych i najczęściej omawianych przez polityków, naukowców i media w Wielkiej Brytanii i w Polsce zagadnień - migracji Polaków do Wielkiej Brytanii. Głównym celem jest zidentyfikowanie istotnych czynników powodujących migrację Polaków na terytorium Wielkiej Brytanii. Autorzy starają się zbadać czynniki przyciągające Polaków do różnych regionów Wielkiej Brytanii, jak poziom płac czy wskaźnik zatrudnienia. W pracy analizowano gdzie i dlaczego polscy emigranci mieszkają w Wielkiej Brytanii, na podstawie danych z Labour Force Surveys, zebranych przez rząd Wielkiej Brytanii oraz danych udostępnionych przez Główny Urząd Statystyczny (GUS) w Polsce. Najważniejszym czynnikiem wpływającym na osiedlanie się Polaków w danym regionie Wielkiej Brytanii jest liczba Polaków w tym regionie w przeszłości. Polacy, przemieszczając się w obrębie Wielkiej Brytanii, mają tendencję do wyboru regionu o wyższym poziomie wynagrodzenia brutto. Wydaje się jednocześnie, że nie biorą pod uwagę zagrożenia bezrobociem.

Autorzy są wdzięczni organizacjom wymienionym w rozdziale Dane $i$ metody za udostępnienie danych ankietowych. Dane LFS zostały udostępniane przez UK Data Service. Poglądy przedstawione w opracowaniu nie odzwierciedlają opinii organizacji, które udostępniły dane.

\section{Introduction}

The free movement of persons is one of the major rights guaranteed by EU. Although the free movement of labour is one of the four freedoms of the $\mathrm{EU}^{1}$, member states are able to delay this process by seven years. For example, countries such as Austria and Germany used their national policies to manage their labour markets until 2011 when the transitionary period of $2+3+2$ years came to an end. Since the UK was one of the countries who did not impose such restrictions, there has been an increase in migration to the UK from the Central and Eastern (CEE) European countries following their EU accession (Office for National Statistics, 2015).

\footnotetext{
${ }^{1}$ Free movement of goods, services, labour and capital.
} 
In Poland, international migration is a phenomenon of socio-economic development, which intensified after the accession of Poland to the EU in 2004. Hence, in the initial period of Polish membership in the EU, we observed a significant increase in immigration from Poland. The EU accession treaty stipulated a transition period of up to seven years before free movement of people was allowed. Only three countries of the EU15: the UK, Ireland and Sweden, agreed to free their labour market: the whole potential flow of emigrants from Poland was now directed to only three of them. Otherwise, migration could have dispersed across 15 countries. The UK was the largest labour market, hence it became the main target migration from Poland (OKÓLSKI, SALT 2014). The number of people leaving Poland varied from year to year; this is a growing trend.

This article focuses on migration of Poles to Britain. The main aim is to identify important factors causing migration of Poles in the UK regions. In this paper, the authors are looking for the answer to what economic factors pull Polish people to different areas in the UK: the level of wages, or unemployment rate.

This paper analyses the location of Polish migrants in Britain. Data from "Labour Force Survey" collected by the UK government, and data from Główny Urząd Statystyczny (Central Statistical Office in Poland) are used.

\section{Literature review}

There are different definitions of migration and migrants; the simplest and the most well understood is the definition of UN from 1998. It defines the international migrant is defined as a person who changes country of residence (usual residence, or the place where he usually in resides, i.e. he/she lives and spends most time). Migration is divided into long- and short-term. Long-term migration concerns a person who changes country of residence for at least 12 months; short-term migration concerns movements of more than 3 months but less than 12 months (excluding recreational or medicinal trips, visits to relatives and friends, business travel, or pilgrimage).

Academic research on migration has many aspects: sociological, geographical, political, historical, economic, demographic, and psychological (BRETTELL, HolliFiELD 2007, p. 3-21). Due to the complexity of the phenomenon of migration, the literature is very rich. Migration of Poles to the UK is often discussed: sometimes in a broader context, for example BAUERE et al. (2006, p. 7-19) and MCCollum and Findlay (2011, p. 1-13) analysed data on A8 migration to the UK during the recessions - describing spatial, temporal and sectoral trends. They noticed the decline has been uneven, with demand for 
migrant labour being most persistent in agriculture. Conducting research on the phenomenon of migration is important because of the increase in its scale.

In the literature, migration is classified as temporary or permanent. This is important, because statistical data in Poland contain information about temporary migration. Temporary migration is when migrants scheduled to return to their country of origin; migration is permanent if the migrant intends to remain permanently at the destination. A key difference is that temporary migrants keep a residence in the source country, whereas permanent migrants do not (OKÓLSKI, 2005, p. 82-83, ORGANIŚCIAK-KRZYKOWSKA 2015). ORGANiŚCIAK-KRZYKOWSKA and MACHNIS-WALASEK (2014, p. 82) refer to a specific form of temporary migration: seasonal, where the migrant works in UK during certain times of year - for example, associated with agricultural work. Owen, FiHel and Green (2007, p. 1, 2) analyse where Polish workers live in UK.

Neoclassical economic theory regarding migration is a relatively simple approach, focusing on wage differences and probability of obtaining work as the motive for migration; it considers costs, as well as benefits, of migration (KUREKOVA 2011, p. 5).

Previous migration literature can be divided into the "disequilibrium perspective", popular before the late 1970s, which assumed migration can increase utility as migrants increase their own income; and the "equilibrium perspective", in which higher-wage locations are associated with higher costs of living, and hence migration may not make a migrant happier (GREENWOOD 2005, p. 726-727, BODVARSSON, VAN DEN BERG 2013, p. 34). OKÓLSKI (2005, p. 231-233) considers migration to be caused by imperfections in the market mechanism within a country - labour mobility between countries improves the allocation of labour, thereby equalizing inequality on a global scale.

Some writers (e.g. ESPÍNDOLA et al. 2006, p. 603-609) use a more complicated model, based on ideas of Harris and Todaro: it assumes each person acts rationally, attempting to obtain the maximum expected income - for example, a person might move to a location with a higher wage, or a lower unemployment rate.

We can consider a number of extensions to the model: such as, people are more likely to move to a country with a relatively low cost of living (ORGANIŚCIAK-KRZYKOWSKA 2015). However, there are practical problems with such models: there are thousands of possible factors which might seem relevant, such as the availability of local churches; access to schools considered suitable; and quality of housing. Public goods such as parks may also affect a decision to migrate, according to the "Tiebout hypothesis" (BODVARSSON, VAN DEN BERG 2013, p. 35). Many of these factors are difficult or impossible to measure. 
Analysis by LEE (1966, p. 47-57) is based on the "gravity model": taking into account the positive correlation between the intensity of migration, and the power of attraction of the target territorial unit he formulated a sociological theory of the "push-pull theory";

According OKÓLSKI (2005, p. 232), the flow of migrants is a function of push factors (which encourage people to leave one location), and pull factors (which attract migrants to a new location). In addition, there are so-called indirect obstacles (intervening obstacles); they may be minor, or decisive in preventing mobility; this is mainly related to political aspects (GÓRNY, KACZMARCZYK 2003, p. 40). An example of "push-pull theory" is variation of wages in the destination and the town of immigrant origin.

ORGANIŚCIAK-KRZYKOWSKA (2013, p. 16-17) suggests six "push factors" (which encourage migration from a country) and six "pull factors" (which encourage migration to a country); this sheds light on why so many Poles move to UK: for example, people are more likely to move to a country with a relatively low cost of living.

Information on the experiences of relatives, neighbours and friends are also relevant to migration. A person is more likely to migrate from one country to another if there is a network of people from the sending country, who live in the receiving country (KUREKOVA 2011, p. 10). Polish migration to UK is an example of "spill-over" of migrant from London, due to the development of migrant networks, which consist of informal contacts: between migrants, and between migrants and employers, as well as recruitment agencies and transport companies. The development of migrant networks is made possible by the existence of demand for foreign workers - demand met by Poles (FIHEL, PIĘTKA 2007).

The theory of migration networks (networks migration theory) assumes that the greatest influence on the decision to migrate is interpersonal relationships between former migrants and future migrants. Previous migrants are the best source of information about the benefits of migration, and on ways to avoid problems (JANICKI 2014, p. 8, 9). They can also provide financial assistance to help find a job and get acclimatized, and thus reduce the costs of migration in all its dimensions: economic, social and psychological (ARANGO 2000 , p. 283-296). Each successive wave of migrants can provide similar assistance to the next wave. Migration is therefore a process which itself is self-sustaining. Migration network theory helps to explain migration between countries, irrespective of the reasons that led to the existence of the first flow. The mere existence of former migrant communities in the country can be the basis for forecasting the direction of future cash flows, and migration should be seen as a chain of feedbacks - not as a collection of individual, mutually independent flows (HANNERBERG, HäGERSTRAND 1957, p. 223-224). Awareness 
of such links combines theory with economic migration networks worldsystem theory, assuming maintaining ties among countries by forming ties on an individual basis. This theory can explain differences in the size of migration to the centres of identical attractiveness, as well as explain the existence of intense migration to countries with restrictive immigration policy of family reunification (ARANGO 2000) and return migrations. The disadvantage of this theory is the inability to identify the causes of initial migration. Migration networks arose before the Polish accession to the EU. After 2004 there is a greater freedom of movement. Despite this, as evidenced by studies conducted by EADE, DRINKWATER and GARAPICH (2006, p. 12-14), migration networks continue to play a vital role in the host country. In the context of the pull and push theory the developed migration network can be regarded as a pull factor.

BURRELL et al. (2009) described both the Polish and British aspects of migration. They analyzed the migration flow, what its causes and effects are, and how these migrants' lives have changed by moving to the United Kingdom.

Economists often use regression to assess such factors; but assessing the effects of relative wages would be complicated because wages vary over time (in response to periods of recession, for example), and the appeal of another country's wage-rate is affected by exchange-rates - which vary all the time. There are practical problems with regression in such cases, because various variables interact - for example, if a large number of people moved from Poland to UK, this may raise the average wage-rates in Poland and reduce the wages in UK, because supply of labour varies; but Polish workers would take skills with them, which would tend to make the UK more productive and hence could increase UK exports and the demand for labour in UK.

\section{Data and methods}

This paper uses "Labour Force Survey" (LFS) data, collected by the UK government (ONS 2015; and earlier LFS surveys). LFS surveys are carried out each quarter, and are nationally representative of the UK. The data refers to the 11 "standard regions" of UK, excluding Northern Ireland. In this paper, "London" refers to Greater London (inner and outer London); all regions in this paper are in England, except Scotland and Wales. The data concern the fraction of people who are born in Poland from the previous year, unemployment rate and gross pay. Data for 2010 to 2014 are analysed. 


\section{Empirical results}

International migration is a socio-economic phenomenon permanently inscribed in modern Polish history. After a drop in 2008-2010 in the number of Poles living temporarily abroad, 2014 saw another increase in the emigration of Poles to other countries - where growth was higher than in the previous year.

Data presented by the Central Statistical Office (Poland) apply to people who are permanent citizens of Poland, but reside outside the country. Because these people have not moved out of permanent residence in Poland, it can be assumed that the departure is not final.

The number of emigrants amounted to 18 thousand in 1990; 22 thousand in 2005; and reached a peak of 47 thousand in 2006. The global financial crisis in 2007 caused a noticeable drop in the number of Poles temporarily residing abroad (35 thousand in 2007; 30 thousand in 2008; 19 thousand in 2009; 17 thousands in 2010), but there was another increase after 2010 (20 thousand in 2011, 21 thousand in 2012, 32 thousand migrants in 2013) (Central Statistical Office 2016, p. 21).

According to data from the Central Statistical Office in 2014, about 2.320 milion Polish people stayed temporarily outside Poland. This is 124 thousand (5.6\%) more than in 2013. In 2014, approximately 2.013 milion Poles were staying outside the country, with the vast majority about 1.901 million resident in the EU. This number increased by 112 thousand compared to 2013 (Central Statistical Office 2016).

The main directions of departure in 2014 from Poland are to developed EU countries such as Germany, United Kingdom and the Netherlands. Among EU countries, most people still were in the UK (685 thousand), Germany (614 thousand), Ireland (113 thousand), the Netherlands (109 thousand), and Italy (96 thousand) (Informacja o rozmiarach $i$ kierunkach... 2014, p. 2). In the UK, there were 642 thousand Poles in 2013 (Informacja o rozmiarach $i$ kierunkach... 2014, p. 2). In 2014, the main destination countries of migration of Poles were United Kingdom and Germany; United Kingdom remains in first place. In the United Kingdom, there was an increase of 43 thousand (6.7\%) compared to 2013 (see Fig. 1) (Gtówne kierunki... 2014). The data are shown in Figure 1, which also shows the growing trend of permanent migration from Poland to the UK from 2002 to 2014.

Figure 2 reports the prevalence of Polish people in standard regions of Britain: Scotland and Wales, then English regions listed approximately from south to north. London has the highest fraction of residents who were born in Poland. In choosing where to live in a foreign country, migration networks play an important role; London is the region with a strong historical migration 


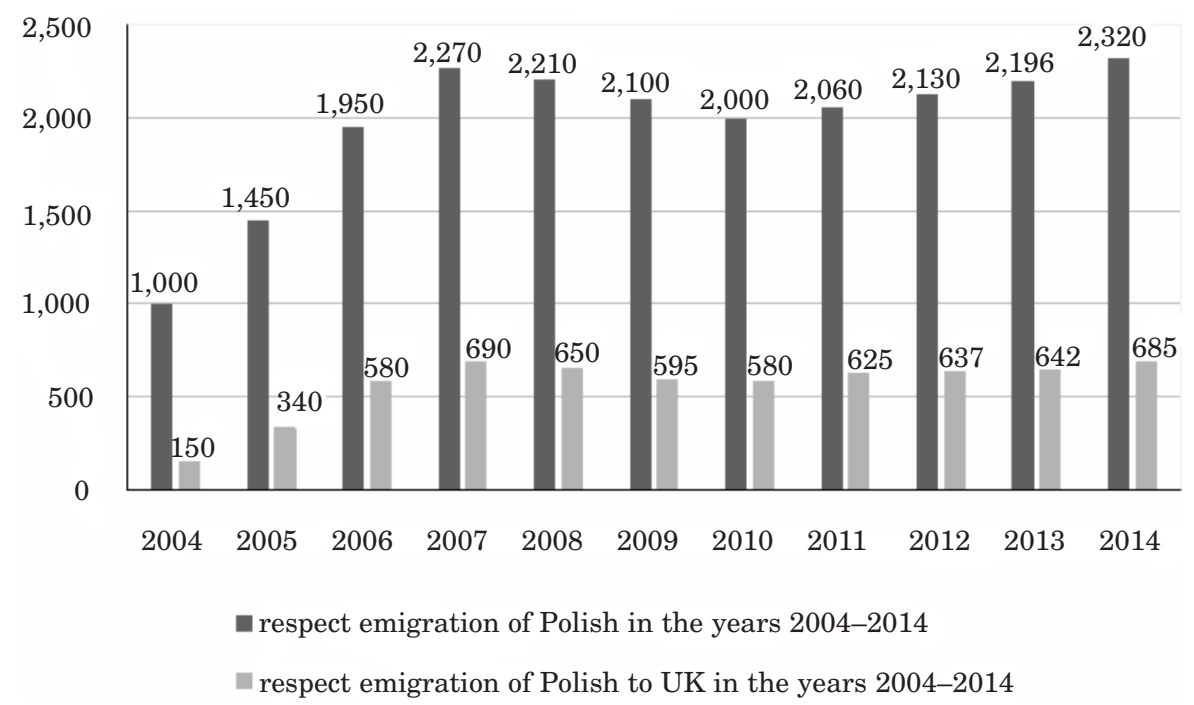

Fig. 1. Numbers of migrants (in thousands) from Poland in years 2004-2014 Data refer to the number of people staying abroad temporarily: for the years 2002-2006 - more than two months, for the years 2007 to 2014 - over 3 months Source: based on Central Statistical Office of Poland (Gtówne kierunki... 2014).

network of Polish people since the Second World War. In recent years, this migration network developed because there were cheap and convenient flight and bus connections.

Figure 3 shows the average pay of people in different UK regions (for all people in that region, not just Poles). The mean gross pay in London is distinctly higher than in other regions; this is a pull factor for migrants. The regions with the highest unemployment rate were Northern England, London, and Yorkshire/Humberside. The next highest pay is South-East England, the region near London. Figure 3 compares wages in different UK regions, assuming one motive for Polish migrants to settle in a region is because it that region's jobs tend to be highly-paid. The average pay shown in Figure 3 is based on people who are employed.

Figure 4 shows a different reason to choose a particular region: unemployment. For a Pole choosing where to live, Figure 4 shows a very different motivation to Figure 3: a region with high pay (e.g. London) does not always have low unemployment. As shown in Figure 4, London had the second-highest unemployment (except in 2014, when Yorkshire \& Humberside had slightly higher unemployment). We are left with a question: do Polish migrants choose regions with higher pay, or lower unemployment? To answer this question, we turn to regression analysis. 


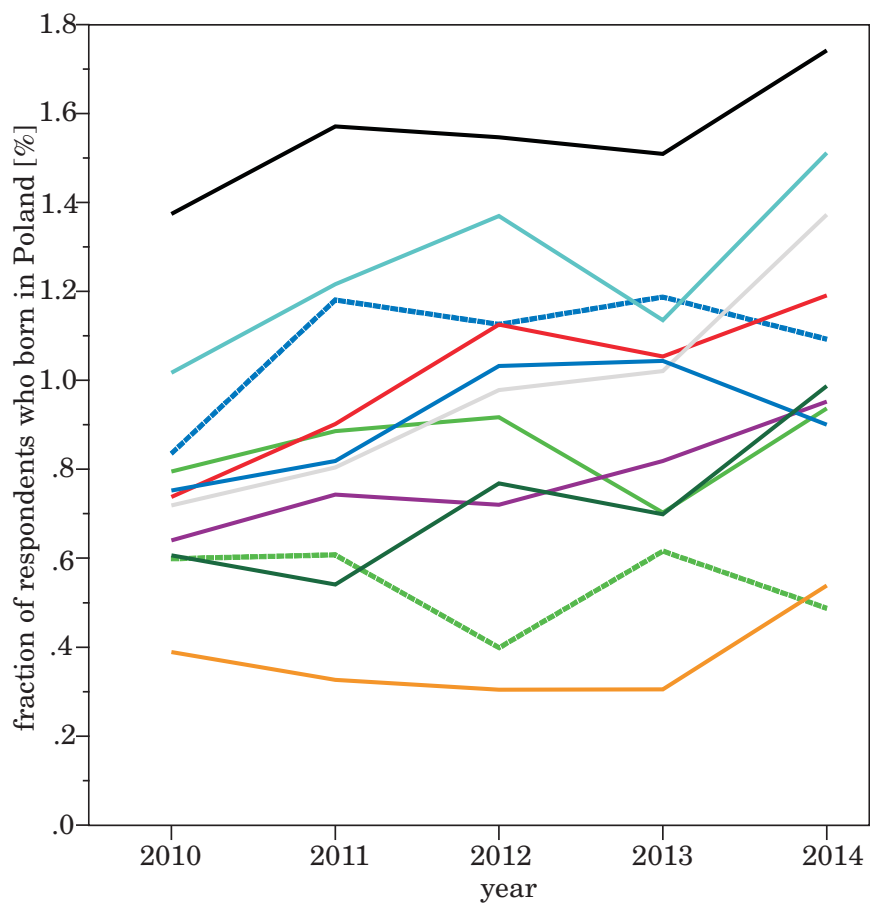

region

- Scotland

- Wales

- South-West England

- South-East England

- London

- East Anglia

- East Midlands

- West Midlands

- Yorkshire \& Humberside

- North-West England

- Northern England

Fig. 2. Immigration from Poland to UK by year and region, 2010 to 2014

Source: the authors, based on LFS data.

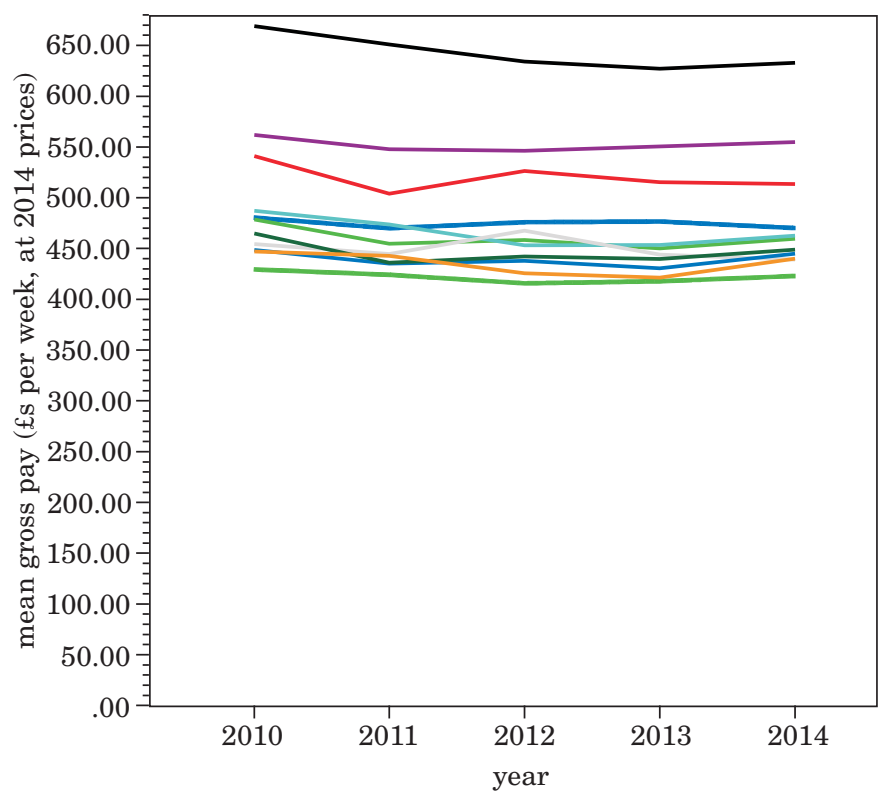

region

- Scotland

- Wales

- South-West England

- South-East England

- London

- East Anglia

- East Midlands

- West Midlands

- Yorkshire \& Humberside

- North-West England

- Northern England

Fig. 3. Gross pay per employed person, by year and region

Source: the authors, based on LFS data. 
Similar conclusions can be read in Work Service (2015), which shows that the main reason for emigration is the opportunity to find much better work: 84 percent of Poles indicated higher salaries as the reason for migration.

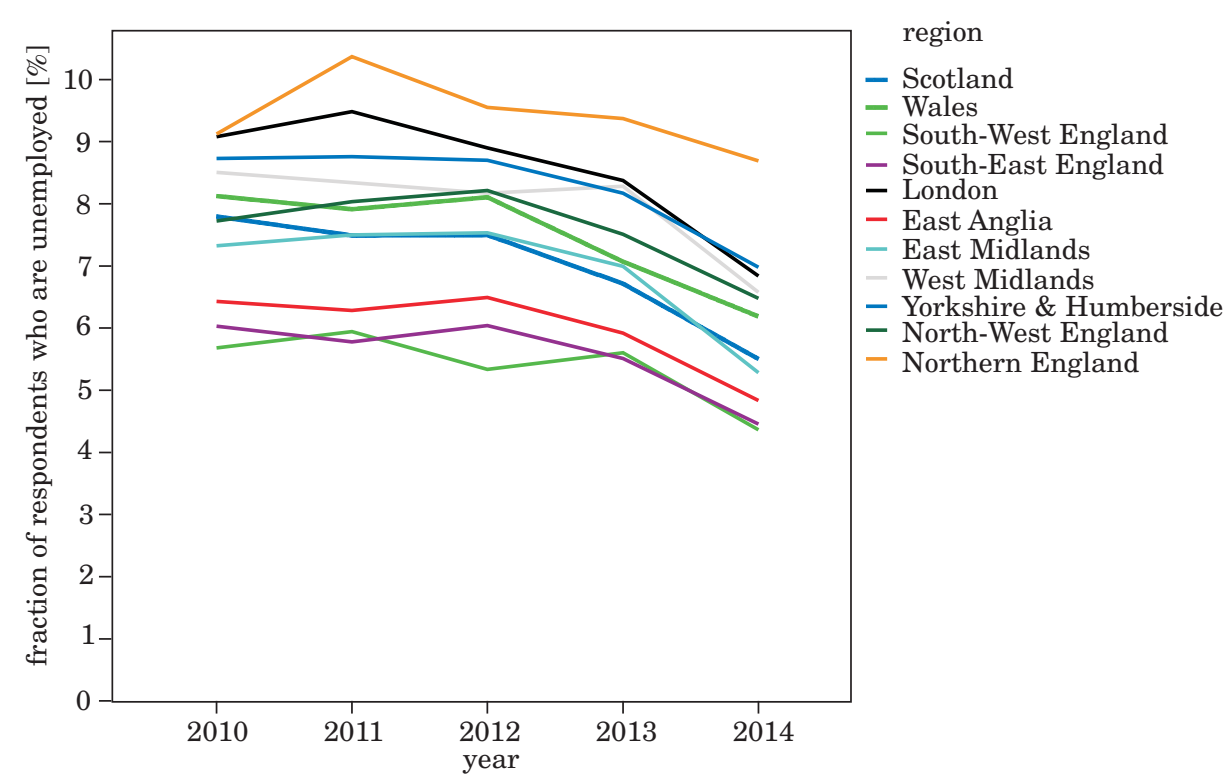

Fig. 4. Unemployment rate, by year and region Source: the authors, based on LFS data.

To find the main factors determining the UK region chosen by Polish People, cross-sectional regression was used. The left-hand side (LHS) variable was fraction of people who were born in Poland and resident in UK $\left(b p_{i}\right)$. The potential right hand side (RHS) variables were:

- fraction of people born in Poland this and previous year, living in $i^{\text {th }}$ region of UK $\left(b p_{-1, i}\right)$;

- unemployment rate in $i^{\text {th }}$ region of $\mathrm{UK}\left(u n_{i}\right)$;

- unemployment rate a year before in $i^{\text {th }}$ region of $\mathrm{UK}\left(u n_{-1, i}\right)$;

- gross pay in $i^{\text {th }}$ region of UK $\left(g p_{i}\right)$;

- gross pay a year before in $i^{\text {th }}$ region of UK $\left(g p_{-1, i}\right)$.

The unemployment rate used here is the fraction of LFS respondents who were unemployed. Gross pay was measured by average level per week, at 2014 prices. As a first step, the correlation matrix between all considered variables for given year was calculated. The chosen correlation coefficients are presented in Tables 1 and 2. 
One can see that in analysed periods, unemployment rate has no significant influence for fraction of Polish people. The most important right hand side variable was the fraction of Polish people a year before. A significant variable is gross pay. All analysed variable are strongly autocorrelated. Analysing all years, one can see that the main factor describing the fraction of Polish people in given year is the fraction of Polish people in that region a year before. The unemployment rate has no significant influence on dependent variable. There is quite a strong correlation between the fraction of Polish people in a region, and gross pay in that region.

Table 1

Serial correlation coefficients

\begin{tabular}{|c|c|c|c|c|}
\hline \multirow{2}{*}{} & \multicolumn{4}{|c|}{ Year } \\
\cline { 2 - 5 } & 2011 & 2012 & 2013 & 2014 \\
\hline$b p_{i}$ and $b p_{-1, i}$ & $0.9541^{* * *}$ & $0.9203^{* * *}$ & $0.9299^{* * *}$ & $0.8564^{* * *}$ \\
\hline$u n$ and $u n_{-1, i}$ & $0.9592^{* * *}$ & $0.9683^{* * *}$ & $0.9266^{* * *}$ & $0.9674^{* * *}$ \\
\hline$g p_{i}$ and $g p_{-1, i}$ & $0.9896^{* * *}$ & $0.9677^{* * *}$ & $0.9806^{* * *}$ & $0.9891^{* * *}$ \\
\hline
\end{tabular}

*** indicates significance at 0.01 level.

Source: own calculations. based on LFS data.

Table 2

Correlation coefficients

\begin{tabular}{|c|c|c|c|c|}
\hline \multirow{2}{*}{} & \multicolumn{4}{|c|}{ Year } \\
\cline { 2 - 5 } & 2011 & 2012 & 2013 & 2014 \\
\hline$b p_{i}$ and $u n_{i}$ & -0.1082 & -0.0982 & -0.0640 & -0.2278 \\
\hline$b p_{i}$ and $g p_{i}$ & $0.6404^{* *}$ & $0.6044^{* *}$ & $0.6190^{* *}$ & $0.6043^{* *}$ \\
\hline
\end{tabular}

** indicates significance at 0.05 level.

Source: own calculations. based on LFS data.

The cross sectional regression was estimated for each year: models with different independent variables were taken into consideration. We assumed that the fraction of people who are born in Poland a year before $\left(b p_{-1, i}\right)$ depends on lagged variables such as: gross pay, unemployment rate and people who are born in Poland. We can write the regression function in general form:

$$
b p_{i}=a_{0}+b p_{-1, i}+u n_{i} u n_{-1, i}+g p_{i}+g p_{-1, i}+\varepsilon
$$

where:

$\varepsilon$ - random term. 
In each year, the gross pay a year before $\left(b p_{-1, i}\right)$ and unemployment rate a year before $\left(u n_{-1, i}\right)$, have no significant influence for fraction of People born in Poland (Tab. 3).

Regression equations show that the fraction of people born in Poland is characterized by huge inertia ( $b p_{-1, i}$ coefficients are statistically significant); the most important factor determining the fraction of Polish people in a given region is the fraction of Poles in that region in the past.

Table 3

The regression coefficients

\begin{tabular}{|c|c|c|c|c|c|}
\hline Year & $a_{0}$ & $b p_{-1, i}$ & $g p_{-1, i}$ & $u n_{i}$ & Adjusted $R^{2}$ \\
\hline & -0.0013 & $1.2680[0.0001]$ & $0.0000[0.7164]$ & $-0.0131[0.6432]$ & 0.883 \\
2011 & -0.0024 & $1.2598[0.0001]$ & $0.0000[0.6670]$ & & 0.893 \\
& -0.0015 & $1.3098[0.0000]$ & & & 0.901 \\
\hline & 0.0006 & $1.0873[0.0009]$ & $0.0000[0.9021]$ & $0.0016[0.9653]$ & 0.790 \\
2012 & 0.0007 & $1.0858[0.0004]$ & $0.0000[0.8996]$ & & 0.813 \\
& 0.0003 & $1.0694[0.0000]$ & & & 0.832 \\
\hline \multirow{3}{*}{2013} & -0.0032 & $0.7387[0.0005]$ & $0.0000[0.2927]$ & $0.0211[0.5051]$ & 0.846 \\
& -0.0014 & $0.7357[0.0000]$ & $0.0000[0.2963]$ & & 0.855 \\
& 0.0017 & $0.8211[0.0000]$ & & & 0.851 \\
\hline \multirow{3}{*}{2014} & -0.0045 & $0.8610[0.0103]$ & $0.0000[0.4092]$ & $0.0024[0.6681]$ & 0.668 \\
& -0.0022 & $0.0083[0.0063]$ & $0.0049[0.4253]$ & & 0.698 \\
& 0.0013 & $0.0095[0.0004]$ & & & 0.707 \\
\hline
\end{tabular}

* the $p$-value is shown in brackets.

Source: own calculations.

\section{Conclusion}

The biggest fraction of Polish people in UK lives in London. This region is characterized by quite a high unemployment rate, but also by the highest gross pay. A migration network from Poland to London has developed since The Second Word War; this could be one of the reasons that the fraction of Polish people is biggest in London.

In 2011-2014, the regions with the lowest rate of Polish people were Wales and Northern England. In these regions, the mean gross pay was the lowest. In Northern England, there was the highest unemployment rate; but in Wales, unemployment rate was at an average level.

The correlation analysis shows that gross pay is a more important variable for describing the fraction of Polish people than the unemployment rate. Polish people choose a region with a higher level of gross pay, and they don't consider the problem of unemployment.

The regression equations show that the fraction of people born in Poland is characterized by huge inertia. So the most important factor determining the 
fraction of Polish people in a given UK region is the fraction of Polish people in that region in the past.

Translated by AuTHORs

Proofreading by JoHN SimisTER

Accepted for print 30.06.2016

\section{References}

ARANGO J. 2000. Explaining migration: a critical view. International Social Science Journal, 52(165): $283-296$.

Bauere V., Densham P., Millar J., Salt J. 2007. Migrants from central and eastern Europe: local geographies. Popul Trends, 129: 7-19.

Bodvarsson Ö.B., van DEN Berg H. 2013. The Determinants of International Migration: Theory. Chapter 2. The Economics of Immigration: Theory and Policy, DOI 10.1007/978-1-4614-2116-0_2, www.springer.com/cda/content/document/cda_downloaddocument/9781461421153-c1.pdf.

Brettell C.B., Hollifield J.F. 2007. Migration Theory: Talking Across Disciplines. Routledge, New York.

Burrell K. 2009. Polish Migration to the UK in the 'New' European Union: After 2004. Aldershot, Ashgate.

Eade J., Drinkwater S., Garapich M.P. 2007. Class and ethnicity: Polish migrant workers in London. Centre for Research on Nationalism, Ethnicity and Multiculturalism, University of Surrey, http://www.surrey.ac.uk/Arts/CRONEM/polish/POLISH_FINAL_RESEARCH_REPORT_WEB.pdf.

Espíndola A.L., Silveira J.J., Penna T.J.P. 2006. A Harris-Todaro agent-based model to rural-urban migration. Brazilian Journal of Physics, 36(3a): 603-609, www.scielo.br/scielo.php?pid=S010397332006000500002\&script $=$ sci_arttext.

Finel A., PięTKA E. 2007. Funkcjonowanie polskich migrantów na brytyjskim rynku pracy. Formerly ISS Working Papers, series: Prace Migracyjne, 23/81, Centre of Migration Research, Faculty of Economic Sciences, Warsaw University, www.migracje.uw.edu.pl/download/publikacja/603.

Gtówne kierunki emigracji i imigracji $w$ latach 1966-2014 (migracje na pobyt stały). 2014. Główny Urząd Statystyczny, Departament Badań Demograficznych i Rynku Pracy, http://stat.gov.pl/obszary-tematyczne/ludnosc/migracje-ludnosci/glowne-kierunki-emigracji-iimigracji-w-latach-1966-2014-migracje-na-pobyt-staly,4,1.html.

GóRNy A., KaCZMARCZYK P. 2003. Uwarunkowania i mechanizmy migracji zarobkowych $w$ świetlne wybranych koncepcji teoretycznych. Prace Migracyjne, 49.

Greenwood M.J. 2005. Modeling migration. In: Encyclopedia of social measurement. Vol. 2. Ed. K. Kempf-Leonard. Elsevier, Amsterdam.

Hannerberg D., HäGerstrand T. 1957. Migration in Sweden. A symposium. Lund Studies in Geography, Series B, Human Geography, 13.

Informacja o rozmiarach i kierunkach czasowej emigracji z Polski w latach 2004-2013. 2014. Główny Urząd Statystyczny, Departament Badań Demograficznych i Rynku Pracy, Warszawa, http://stat.gov.pl/obszary-tematyczne/ludnosc/migracje-ludnosci/informacja-o-rozmiarach-ikierunkach-emigracji-z-polski-w-latach-20042013,2,7.html.

Informacja o rozmiarach i kierunkach czasowej emigracji z Polski w latach 2004-2014. 2015. Główny Urząd Statystyczny, Departament Badań Demograficznych i Rynku Pracy, http://stat.gov.pl/download/gfx/portalinformacyjny/pl/defaultaktualnosci/5471/11/1/1/szacunek_e migracji_z_polski_w_latach_2004-2014.pdf.

JANICKI W. 2014. Przeglad teorii migracji ludnosci. UMCS Lublin, http://phavi.umcs.pl/at/attachments/2014/0215/130630-19-przeglad-teorii-migracji-ludnosci.pdf.

Kurekova L. 2011. Theories of migration: Conceptual review and empirical testing in the context of the EU East-West flows. Paper prepared for Interdisciplinary conference on Migration. Economic Change, Social Challenge. 6th to 9th April 2011, University College London, UK.

LEe E.S. 1966. A Theory of Migration. Demography, 3(1): 47-57. 
Machnis-Walasek J., Organiściak-KrzyKowsKa A. 2014. Return Migration of Higher Educated Poles in Times of Economic Crisis. The Macrotheme Review: A Multidisciplinary Journal of Global Macro Trends, 3(2): 71-84.

McCollum D., Findlay A. 2011. Trends in A8 migration to the UK during the recession. Population Trends, 145.

Migracje zarobkowe Polaków. 2015. Raport Work Service S.A., www.workservice.pl/Centrumprasowe/Informacje-prasowe/Ekspert-HR-komentuje/Az-1-2-mln-Polakow-zdecydowanych-naemigracje-zarobkowa.

Okólski M. 2005. Demografia. Podstawowe pojęcia, procesy i teorie w encyklopedycznym zarysie, Wyd. Naukowe Scholar, Warszawa.

Okólski M., SAlt J. 2014. Polish Emigration to the UK after 2004; Why Did So Many Come?. Central and Eastern European Migration Review, 3(2), www.ceemr.uw.edu.pl/vol-3-no-2-december2014/articles/polish-emigration-uk-after-2004-why-did-so-many-come.

ONS. 2015. Quarterly Labour Force Survey, October-December, 2014 [data collection]. UK Data Service. SN: 7664. Office for National Statistics, http://dx.doi.org/10.5255/UKDA-SN-7664-1.

Organiściak-KrzyKowsKa A. 2013. Contemporary conditions and directions of migration in Poland: Returns from migrating to the annual operating on the market situation to Poland. UWM Publishing, Olsztyn.

ORGANiściaK-KRZYKowsKa A. 2015. Reasons for and directions in Poles' temporary migrations. PowerPoint presentation: University of Warmia and Mazury in Olsztyn.

ORGANiŚCIAK-KRZYKOWSKA A., MACHNIS-WALASEK J. 2014. Edukacyjne uwarunkowania powrotów Polaków z emigracji zarobkowej. Acta Universitatis Lodziensis. Folia Oeconomica, 3(303): 61-75.

Owen D., Finel A., Green A. 2007. Najnowsza migracja z Polski do Wielkiej Brytanii. Biuletyn Migracyjny, 12, www.biuletynmigracyjny.uw.edu.pl.

Poland in the European Union. 2016. Główny Urząd Statystyczny, Departament Badań Demograficznych i Rynku Pracy, http://stat.gov.pl/obszary-tematyczne/ludnosc/migracje-ludnosci/glownekierunki-emigracji-i-imigracji-w-latach-1966-2014-migracje-na-pobyt-staly,4,1.html.

Sytuacja demograficzna Polski. Raport 2010-2011. 2011. Ed. Z. Strzelecki. Rządowa Rada Ludnościowa, www.stat.gov.pl/cps/rde/xbcr/bip/BIP_raport_2010-2011.pdf. 